\title{
The 26th International Geological Congress, Paris, 1980
}

\author{
President of COFRHIGEO (Paris), 2 Avenue Bernard Palissy, 92210 St Cloud, France.E-mail: ga.gohau@wanadoo.fr
}

In 1878, France hosted the first International Geological Congress on the occasion of the International Exhibition held in Paris that year. The decision to hold such a meeting in France had been taken two years earlier at the Exhibition in Philadelphia. France also wished to host the centenary Congress (102 years in fact, because of the pattern of meetings established after the Second World War), as this corresponded with the 150th year of the foundation of the Geological Society of France in 1830, on the initiative of Ami Boué and Constant Prévost, who were elected President and Secretary. Happily, this wish was fulfilled (see Figure 1).

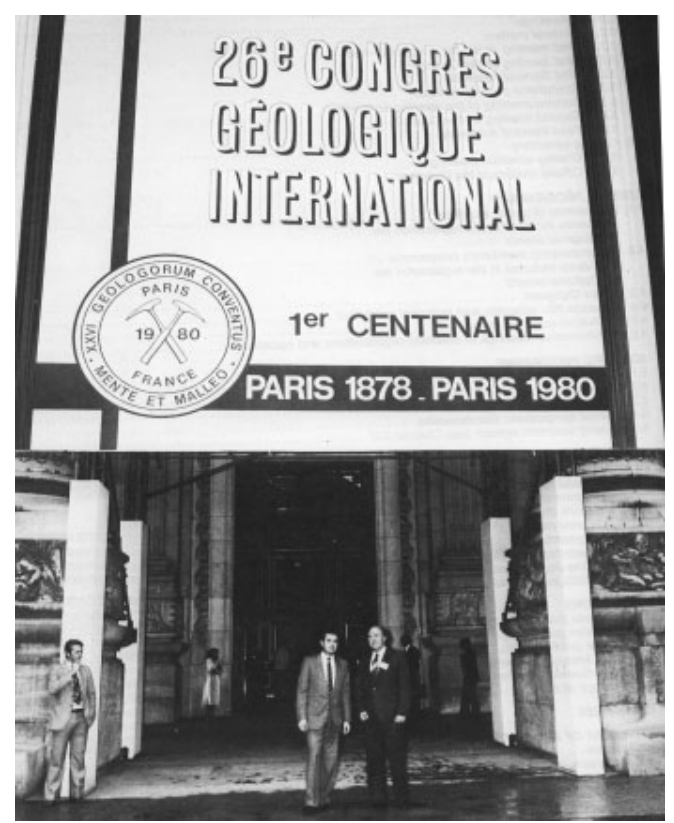

Figure 1 Prof. Jean Aubouin and Paul Sangnier, President and Secretary of the 26th International Geological Congress in the front of Palais de Chaillot, the venue of Congress at Paris.

Jean Goguel proposed the Paris meeting for 1980 at the Montreal Congress in 1972, specifying that he would like the "proposal to be formulated by a group of western European nations, which would not only emphasize the unity of geological problems that face us, but also the sentiment that we have of our common destiny and our willingness to undertake it together". The invitation from France was formally presented at the Council Meeting of the 25th Congress in Sydney, supported by the United States and Spain. And on 25 August, 1976, at that Congress's closing ceremony Alain Perrodon, President of the French National Geological Committee, invited all the delegates to Paris four years later, for the centenary meeting. It was to be the third Congress meeting to be held in the French capital, since France had also been chosen for the 8th meeting in 1900, in order to coincide, once again, with a Paris International Exhibition. The first two Congresses were held at the Trocaderro, on the site of the Palais de Chaillot, on the western side of Paris.

\section{The opening and closing ceremonies}

The 1980 Congress was also held on the western side of Paris, but further from the city centre, at the Palais des Congrès (Porte Maillot). The Porte Maillot is situated at the end of L'Avenue de la Grande Armée on the famous axis that connects the Louvre and the Tuileries gardens to the so-called Tours de la Défense (in a suburb of Paris with multiple towers, twenty to thirty stories high), passing the Place de la Concorde, the Champs-Élysées and the Place de l'Étoile. The Palais des Congrès was of recent construction. Built on the site of a former amusement park, it had been opened in 1974, after four years of construction work. The architects were Gillet, Guibout and Maloletenko. Its horizontal extension was emphasized by the height of an immense hotel tower, standing at its rear. The first event there was a sound festival, and in 1979 there was the first of a long series of musical comedies: Starmania. The Geological Congress was perhaps finding its 'natural place' there!

As to participants: the total number of enrolments was 4883, with 4541 actually attending (including the student members). With 839 accompanying members, the grand total for the attendance was 5722. 116 countries were represented. By comparison, 2953 people attended the Sydney Congress in 1976, and 3896 had been at the Montreal meeting in 1972, with 85 and 110 countries represented respectively.

The meetings were held from 7 to 17 July, and divided into Sections, including a history of geology meeting; and 7 colloquia plus a special symposium. There were also geological excursions and one related to the history of geology.

The Congress President was the tectonics authority, Professor Jean Aubouin, of Paris-6 University. Aged 52, he had first become known for his notable thesis on the Pinde Chain in Greece, where he rediscovered a geosynclinal structure that had previously been described a hundred years previously. His investigations on the topic contributed to understanding the genesis of the circum-Mediterranean mountain chains, thereby preparing people for the revolution in global tectonics, which Aubouin quickly adopted.

The Secretary-General was Paul Sangnier, who as a young man had been an engineering geologist at the Bureau de Recherches Géologiques et Minières for ten years. He left his position as scientific adviser to the Délégation Générale à la Recherche Scientifique et Technique in 1978 to devote all his time to the preparation of the 26th Congress. After the Congress, with a bright future ahead of him, he became Director of the French Geological Survey, a position that enabled him to fulfil his passion for finding new sources of energy and for renewable energies. But sadly he died prematurely on 26 October, 1983, aged 45.

The opening ceremony (see Figure 2) began at 5 p.m. on 7 July in the 'nave' of the Grand Palais, a building located near the Champs-Élysées, to the right of the Alexander III bridge, and frequently used for exhibitions, as was the celebrated Palais de la Découverte. The Minister for the Environment, Monsieur Michel d'Ornano, declared the meeting open, followed by the Zurich professor Rudolf Trümpy, retiring President of the International Union of Geological Sciences. It was followed, in accordance with the statutes, by a General Assembly of Congress, arranged by the Organizing Committee and Council. In addition, in accordance with tra- 

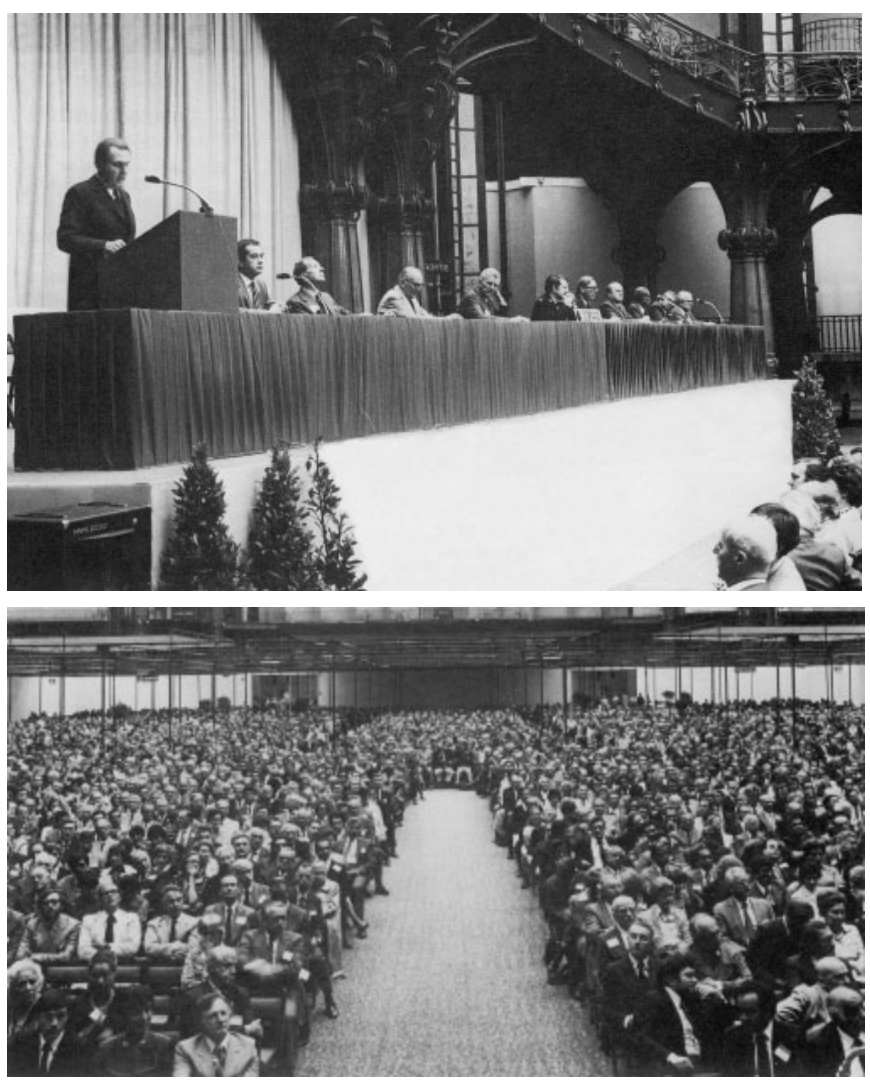

Figure 2 The leaders (above) and participants (below) at the Opening Ceremony of the 26th Congress.

dition, the Academy of the USSR presented the Spendiarov Prize to René Blanchet, Professor of Geology at the University of Brest*.

The opening scientific session was presided over by Pierre Aigrain, Secretary of State for Research. Six major themes were addressed: Jean Aubouin, on Orogenesis (from former ocean basins to mountain chains); L. Silver on Exploration of the planets; D. McKenzie on Causes of plate movements; G. Eglinton on Molecular palaeontology; E. Picciotto on Mankind as a geological agent; and lastly R. A. Price, introducing a new international programme on the Dynamics and evolution of the lithosphere.

The closing ceremony took place on 17 July at 3.30 p.m., in the Large Auditorium of the Palais des Congrès, with 3,000 people present. The event consisted of three components: the final General Assembly; the closing scientific meeting; and the official closing of the Congress. The closing scientific meeting took place at 4.30 p.m., under the chairmanship of Madame Alice Saunier-Seïté, Minister for Higher Education. The first speech was by Professor Eugen Seibold, the incoming President of the IUGS, about geology in the eighties; and the second was by Dr J. Bodelle, Director of the National Geological Survey. It was followed by a final speech by Madame Saunier-Seité. The official closing ceremony took place under the chairmanship of Valéry Giscard d'Estaing (see Figure 3), President of the French Republic, in the presence of Mme Saunier-Seitté, André Giraud (Minister for Industry), and Pierre Aigrain (Secretary of State for Research). Two speeches were delivered: the first by Jean Aubouin and the second by President Giscard d'Estaing.

The programme for the accompanying members included both the opening and closing ceremonies, a panoramic coach-tour round the town of Paris, a day-trip to Chartres and Orleans, and two scientific lectures by Henri-Jean Schubnel (on precious stones) and by Xavier Le Pichon (about exploration of the oceans). There were also optional visits to the Palace of Versailles, the Gobelin Tapestries, the National Museum of Sèvres Porcelain, the Georges Pompidou

* On the Spemdiarov Prize, see: E. E. Milanovsky, 2004, Three Sessions of the International Geological Congreess, held in Russia and the USSR (1897, 1937, 1984): Episodes, v. 27, pp.101-106.
National Centre of Art and Culture, the Marais, Notre-Dame, or visits to Reims and Rouen. Special gifts to commemorate the Congress were: a Commemorative Medal, a silk scarf specially designed by Hermes-Paris; and a special stamp on 'Sciences of the Earth' issued by the Postal and Telecommunications Service.

\section{The sections}

The sections treated the various branches of geology, some more developed than others. This was clearly the case for the traditional disciplines: petrography, stratigraphy (which itself had sub-sections on the eras that were furthest apart in time: the Precambrian and the Quaternary), and tectonics, along with marine geology, metallogenesis, and hydrogeology. It is not possible to summarize here all that was said. As in all congresses the sections allowed researchers to discuss the most varied topics. A glance at the Congress Programme gives an idea of the main topics addressed. The sections in order were:

Section 1

Petrography (conveners J. Lameyre, A. Weisbrod), with work relating particularly to metamorphism and magmatism in the framework of global dynamics, on ophiolites, and the magmatic evolution of the Andes.

Section 2

Mineralogy (F. Permingeat, R. Pierrot, A. S. Marfunin), a separate discipline in the Congress framework.

Section 3

Palaeontology-micropalaeontology (L. David, J. P. Lehman), with three main strands: palaeoecology, evolution and palaeobiogeography.

Section 4

Stratigraphy (C. Pomerol, P. Rat, M. G. Bassett), with papers representing the work of 300 authors, carried out in all parts of the world, including Antarctica, and the seas and oceans.

Section 5

Tectonics (M. Mattauer, A. Nicolas, J. F. Dewey), with numerous papers reflecting the rapid development of ideas in tectonics in the preceding years.

Section 6

Marine geology-sedimentology-sedimentary petrography (G. Boillot, M. Vigneaux, E. Seibold), on a variety of topics, with 223 presentations programmed.

Section 7

Precambrian (R. Capdevila, M. Gravelle, B. F. Windley), with numerous new results presented.

Section 8

Quaternary geomorphology (H. Faure, P. Rognon, J. M. Soons), one meeting on the theme of the rates of surface processes and nine symposia reflecting the activities of INQUA.

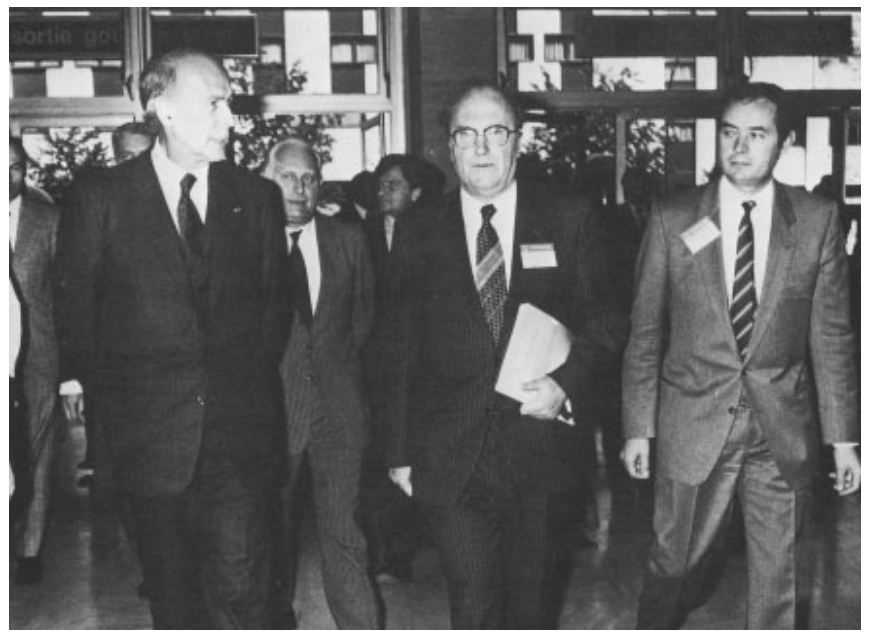

Figure 3 President Giscard d'Estaing in company with the Congress President and Secretary-General. 
Section 9

Geophysics (G. Grau, G. Perrier, S. T. Müller), with seven sessions only; but many papers by geophysicists were allocated to other sections.

Section 10

Geochemistry (F. Albarède, B. Tissot, G. Wetheril), with papers on crust-mantle interaction, the migration and concentration of elements, and geochemical indicators providing the main themes.

Section 11

Remote sensing (A. Fontanet, Y. Vuillaume, C. Voute), which area was included in the International Congress for the first time.

Section 12

Mathematical geology and geo-information science (P. Lameyrie, G. Matheron, R. Sindin-Larsen).

Section 13

Metallogenesis and mineral ores (R. Burnol, Z. Johan, D. Watkinson), a section characterised by the large number of communications: 204 in 23 sessions.

Section 14

Fossil fuels (H. Radier, P. Vetter, A. Van Adrichem Boogaert).

Section 15

Hydrogeology (G. Castany, P. Chauve, A. Berger).

Section 16

Engineering geology and materials (M. Rat, G. Souliez, R. Wolters).

Section 17

Geological hazards (M. Panet, Ch. Weber, F. Barberi).

Section 18

Planetary geology (C. Allègre, J. Audouze, V. Barsoukov).

Section 19

History of geology (F. Ellenberger, J. Gaudant, R. Hooykaas). History of geoscience first became one of the Congress Sections at the previous meeting in Sydney. This innovation, the Section's success, and especially the inclusion of an excursion, about which more will be said below, as much as the fact that the writer of these lines participated in the meetings of Section 19, induce me to provide a full account of this section.

Four years previously, the celebrated structural geologist, François Ellenberger, Professor at the University of Paris-sud Orsay, had founded the Comité Français d'Histoire de la Géologie (COFRHIGEO), conceived as a French section of the International Commission on the History of Geological Sciences (INHIGEO), which was pleased to bring together many of the world's most distinguished historians of geology in the French capital. It was assisted by the palaeontologist Jean Gaudant, Secretary of COFRHIGEO, and had invited the eminent Dutch historian Reijer Hooykaas to participate. The Section had more than forty communications. The meetings were held in part (in the afternoons) in the History Centre in Rue Malher, where Jacques Roger, Vice-President of COFRHIGEO taught. A theme, 'French Geology up to 1832', had been proposed, but only a few of the communications were on this topic. The texts of the papers, or in some cases the abstracts, were regrouped the following year and published in the French journal Histoire et nature, with an introduction by Ellenberger.

There might have been concern that the chosen theme was focused on France too much, and could have discouraged foreign contributors. But this was not the case; for among the speakers were eminent scholars of French geology, such as Kennard Bork, Kenneth Taylor, Rhoda Rappaport, and Cecil Schneer.

\section{The colloquia and the special symposium}

As for the seven colloquia, they represented both the pioneering work being done internationally at that period, and the particular preoccupations of French geologists. Also, it will be no surprise to see meetings concerned with continental margins, on the geology of oceanic regions, and on the Alpine chains that the end-product of the Tethys. This last issue divided into eight themes: alpine America, Alpine Europe, alpine Asia, the birth of alpine Asia, from the Tethys to present intra-alpine seas, relations with palaeontology, tectono- genetic stages (correlation deformation, metamorphism, and magmatism), and finally Tethys and plate tectonics. One can see what had been the research theme for the 1970s. The last two colloquia provided the opportunity to discuss problems of European geology: the successions of orogenesis, from pre-Caledonian mountain ranges to the Alpine orogeny; and French structures of granites, volcanics, metamorphism, and sedimentary basins.

\section{Some details of the colloquia}

Colloquium 1: Mineral resources (conveners $\mathrm{Cl}$. Guillemin, $\mathrm{Ph}$. Lagny)

This had four sessions: geographic and stratigraphic distribution of ore deposits (metallic and metallogenic provinces); relationships between grade and tonnage; mineral exploration and processing methods; and the economy of primary mineral and energy raw materials.

Colloquium 2: Energy resources (conveners P. F. Burolley, V. Ziegler)

There were five sessions, one being common to Colloquium 1 .

1. Hydrocarbons. Several papers discussed development in new areas, in particular those in China and that of Beaufort Sea.

2. Coal.

3. Other energy sources: especially geothermal energy.

4. Uranium.

5. The economic use of primary mineral and energy raw materials (the common session).

The results of the colloquium clearly indicated that a vast effort was still required to evaluate deposits, particular fossil fuels.

Colloquium 3: Geology of continental margins (conveners $\mathrm{R}$. Blanchet, L. Montadert)

Two major themes were dealt with in this colloquium: active and passive margins. In each of these themes papers were devoted to the structural make-up of a margin, to its evolution in the course of time, and finally to geophysical models which might permit the integration and explanation of the main facts. The importance of margins was a new topic in 1980 and the interest in the topic can be gauged by there being a special colloquium devoted to it, which attracted 46 communications. According to the conclusion in the Actes: "The final discussion indicated the great importance of thinking about active margins in terms of time intervals as brief and precise as possible; the active margins are polyphase constructions of the same status as the ocean floors, and it is necessary to seek out the structure of each stage."

Colloquium 4: Geology of oceans (conveners J. Debyser, X. Le Pichon, F. Vine).

The papers presented in the framework of this colloquium can be grouped under three major themes:

1. Oceanic circulation and its consequences on climatology, sedimentology, and geochemistry.

2. The structure and method of functioning of expansion zones.

3 . Changes in the oceanic lithosphere, away from the ridges. On this issue, there were 6 sessions, with 39 oral presentations. It was still a relatively fresh problem, with Vine and Le Pichon, known for their role in the development of plate tectonics.

Colloquium 5: Geology of alpine chains originating from the Tethys (conveners J. Aubouin, J. Debelmas, R. Latreille).

This colloquium had a very ambitious programme: a survey of the fold-belts with the most complex geology in the world, stretching from the Caribbean as far as the borders of the Australia. The volume of papers shows that the proposed objective was attained and the colloquium was a great success. The Europeans compared their ideas, and visitors from other continents retained a more or less accurate impression: an orogeny locally well known in minute detail but still poorly understood overall.

Colloquium 6: Geology of Europe from Precambrian to the postHercynian sedimentary basins (conveners J. Cogné, M. Slansky) For this there were four sessions:

1. The search for primitive oceans

2. The Caledonides 
3. The Variscan domain

4. The post-Hercynian basins.

Colloquium 7: Geology of France (conveners A. Autran and J.

Dercourt).

There were two sessions with 14 oral presentations:

1. Pre-Triassic France

2. Post-Triassic France.

The theme of the special symposium was Geodynamics (conveners A. L. Hales, R. D. Russell). It was organised jointly by the 26th International Geological Congress and the Inter-Union Commission on Geodynamics. 14 oral communications were presented

Altogether, the sections, the colloquia, and the special symposium comprised 2690 abstracts, of which 2148 were presented as oral papers. The languages used were mainly English $(65 \%)$ and French $(30 \%)$

\section{The excursions}

In order to offer members the widest possible choice of geological topics, the Organizing Committee sought the help of the National Committees of the various European countries and eighteen countries (Austria, Belgium, Denmark, Finland, the German Federal Republic, Greece, Iceland, Ireland, Luxembourg, Netherlands, Norway, Portugal, Spain, Sweden, Switzerland, the United Kingdom, and Yugoslavia) were associated with the excursion programme, taking scientific responsibility for the ones that they offered. In France, six associations of geologists (west, east, southeast, southwest, Massif Central and the Paris Basin) prepared regional excursions. In addition, the conveners of eleven scientific sections chose thematic excursions, generally involving several national committees or French regional groups. More than 500 European geologists were thus involved in this programme.

Three types of excursions were provided for: before (A), during (B), and after (C) the Congress. The length of excursions A and C was limited to 9 days. Three type-B excursions were offered: two day excursions on 13 and 14 July, and some one-day excursions, many of which were repeated. The type-A excursions took place between Thursday 26 June and Saturday 5 July. The type-C excursions took place between Friday 18 July and Sunday 27 July.

The first circular initially proposed 216 excursions of type A or C. Finally, only 46 excursions were retained (and 45 took place). By comparison, for Montreal 106 excursions were proposed (First Circular) and 73 were actually carried out. For Sydney the numbers were 92 and 41 . The numbers of participants were: 1646 (Montreal), 1095 (Sydney) and 927 (Paris). The B excursions were most successful: 6 excursions of two days, 26 of one day, and 16 short visits, with a total of 1447 participants.

Several of the excursions were designed for student geologists, such as Excursion 41 (Geological section on foot from north to south in the Central Pyrenees); or Excursion 149 (The Mont Blanc Massif and the Aiguilles Rouges). The excursion that attracted the largest number of participants (39) was very French: on 'Geology and the wines of France'! Excursion 78 (Precambrian ore deposits in Sweden and Finland) was held twice, before and after the Congress. The total number of participants $(27+34=61)$ was thus the highest, overall. Another popular excursion was No. 131: 'Geology applied to regional development, hydrogeology, engineering geology, ecogeology' (in southeastern France and the Federal Republic of Germany) with 37 participants.

Guide-books were specially produced for the excursions: 25 for regional excursions; and 17 for thematic ones. The titles of the regional excursions were: Finland, Iceland, Norway, Sweden, Austria, Germany, United Kingdom, Ireland, Netherlands, Switzerland, Espana (twice), Greece, Italy, Portugal, Yugoslavia, Belgium, Luxembourg, and France: Massif Central, West, Southwest, Southeast, East, Paris Basin, and a volume for the type-B excursions in the Paris Basin.
Among the excursions, one did not have a newly produced guide. This was the excursion concerned with the 'Sources of French geology', organised by François Ellenberger, who had previously published a travel guide, "For the use of the historian of the earth sciences for the itinerary Paris-Auvergne-Marseille", published by the journal Histoire et nature, with the assistance of Georgette Legee, the dedicated editor of that publication. Because of its novelty, and because I am myself an historian of geology and participated in the excursion, I append here a summary of the places visited.

\section{Appendix}

\section{Excursion on the origins of French geology}

Day 1

Paris-Arcy sur Cure-Montbard-Saulieu. The large grotto of Arcy sur Cure is of great importance for the history of speleology, and has long been known and described because of its proximity to Paris. Montbard is well known as the town where Buffon was born. We visited his study, situated by the walkway of the old château of the Counts of Montbard. Near Montbard is Semuren-Auxois, the town after which the Sinemurian (Lower Jurassic) is named and where one can examine the stratotype.

Day 2

Saulieu-Autun-Moulins-Volvic-Clermont-Ferrand. Autun is the locality of the stratotype of the former Autunian stage (Lower Permian). From Moulins to Volvic one follows the route of Guettard who, in July 1751, recognized the volcanic nature of the hills of the Auvergne.

Day 3

Clermont-Ferrand-Puy-de-Dôme-Mont-Dore-Saint-Nectaire. Near Clermont-Ferrand, the plateau of Pradelle is the historic place where Nicolas Desmarest established the volcanic nature of basalt, some ten years after Guettard's journey. As for the Puyde-Dôme, the place where Pascal directed experiments on atmospheric pressure, one could have multiple debates about the absence of a crater. The massif of Mont-Dore, to the south, is (with Cantal) the French 'type locality' for the theory of 'craters of elevation' of Leopold von Buch.

Day 4

Mont-Dore-Issoire-Le Puy. One passes the famous bed of Quaternary fauna of Perrier and reaches Le Puy to view the volcanism of Velay, the volcanoes of which were known to Guettard (1759), Desmarest (1771), Pasumot, Genssane, etc.

Day 5

Le Puy-Pradelles-Thueyts-Antraigues-Aubenas. The day's travel was devoted to the volcanism of the Vivarais, studied by Guettard, Faujas de Saint-Fond, and l'abbé Soulavie. To Aubenas, where one can see a panorama illustrating the structural and Day 6 stratigraphic understanding of Soulavie.

From Aubenas to Alès: Soulavie and de Sauvages. A journey devoted to the beginnings of the stratigraphy of southern France and its two great promoters. The line of section to Largentière, given in Vol. 8 of de Soulavie. Visit to Pont d'Arc, a (too) famous natural site. In the Alès region, one can reconstruct the ideas of l'abbé Pierre-Augustin Boissier de la Croix de Sauvages, published in 1749 and 1750, a leading pioneer in stratigraphy and tectonics through his description of the region, well in advance of his time. The day's journey was completed by a panoramic view of the ten famous chaines distinguished by l'abbé.

Day 7

From Alès to Montpellier, via Uzès and Nîmes. Around Alès we passed close to the coal basin where Sauvages studied plant impressions, and then visited several of the chaînes. Following a traverse of Uzès, there was a stop at the famous Pont 
$d u$ Gard, and then on to Nîmes, whence we arrived at Montpellier.

Day 8

Montpellier-Pézenas-Agde-Montpellier. The journey focused on the volcanism of Languedoc and the intellectual milieux of Montpellier. The descriptions of the engineer Henri Gautier (1723), an important but little-known precursor of Hutton according to Ellenberger, referred to the Villeveyrac, which demonstrated the present erosion of the continent by rivers, forming what he called the répandues. Day 9

Montpellier-Aigues-Mortes-Les Baux-Marseilles. The day's journey began at Camargue with Gautier and concluded at Marseilles chez Benoît de Maillet, author of Telliamed. We passed Orgon, stratotype for the Urgonian Stage (Middle Cretaceous, approximately Barremian). At the outskirts of Marseilles, one could inspect a limestone monocline, dipping at $40^{\circ}$, for which Benoît de Maillet rejected an overturn, inaugurating what Ellenberger called neptunisme antitectonique.

At the conclusion of the intensive and informative excursion, the 21 participants unanimously thanked François Ellenberger and Georgette Legée, who had spared no trouble, saying that they had never been privileged to join an excursion in the history of geology of such breadth and depth.

\section{Sources}

Congress Publications:

1. Programme, 1 volume

2. Proceedings, 1 volume

3. Abstracts of papers, 3 volumes plus authors' index, 2690 abstracts

4. Colloquia:

Mineral resources, 1 volume

Energy resources, 1 volume

Geology of Continental Margins, 1 volume

Geology of Oceans, 1 volume

Geology of Alpine Chains born of the Tethys, 1 volume

Geology of Europe, from the Precambrian to the PostHercynian Sedimentary Basins 1 volume Geology of France, 1 volume

5. Excursion Guide-books: Regional excursions, 25 volumes Thematic excursions, 17 volumes

6. Special publications:

Memoirs on metallogeny, 4 volumes

Booklets on French ore deposits, 10 volumes

European Geology, 4 volumes, consisting of the introductions to the guide-books.

\section{List of CGMW Maps Available}

\section{Geological Maps}

Geological Map of the World (2nd edition)

1:25 M and 1:50 M scales, Arclnfo digital version (2000)

International Geological Map of Africa

1:5 M scale, 6 sheets (completed in 1990)

Geological Map of the Middle East

1:5 M scale, 1 sheet (1993)

Geological Map of South America

1:5.5 M scale, 1 sheet (2001) and Arclnfo version

Geological Map of the Bosumtwi impact crater

1:50 000 scale (2005) + explanatory notes (folded only)

International Geological Map of Europe, 2nd edition (New)

1:5 M scale (2005)

Seismotectonic / Geodynamic Maps

Seismotectonic Map of the World

1:25 M and 1:50 M scales (2001)

Geodynamic Map of the Mediterranean Area

1:10 M scale, 2 sheets (2004)

Seismotectonic Map of the Middle East

$1.5 \mathrm{M}$ scale, 1 sheet (1992)

Tectonic Maps

International Tectonic Map of Europe

1.5 M scale, 5 sheets (1996)

\section{Metallogenic Maps}

Metallogenic Map of South America, 2nd edition (New)

1:5 M scale, 4 folded sheets + explanatory text (2005)

Metallogenic Map of South and East Asia

1:5 M scale, 4 sheets ( +1 legend sheet) (1985)

International Metallogenic Map of Africa

1:5 M scale, 4 sheets (2003)

Mineral Atlas of the World - Europe sheet 9

1:10 M scale (1997) set of printed and digital versions

\section{Seafloor Maps}

Map of the Indian Ocean

1:20 M scale, structural and physiographic sheets (2004)

Geological Map of land and sea areas of Northern

Europe (NGU \& CGMW co-edition)

1:4 M scale (2002)

\section{Metamorphic Map}

Map of the metamorphic structure of the Alps

1:1 M scale (2004)

Metamorphic Map of South and East Asia

1:5 M scale, explanatory notes (1984)

\section{Environmental / Natural Hazards Maps}

Maps of the World Environments during the Last Two Climatic Extremes 1:50 M scale, 2 maps (1999)

Maps of the Mediterranean during the Last Two

Climatic Extremes $1: 7 \mathrm{M}$ scale, 2 sheets (2004)

Map of the Sahara in the Holocene

1:5 M scale (1993)

Eastern Asia geological hazards Map

1:7.7 M scale, 3 sheets + expl. notes (2003) (folded)

Map of groundwater resources of the World

Transboundary Aquifer Systems

1:50 M scale (2006) (folded)

\section{GEOLOGICAL TIME SCALE 2004}

Published by the International Commission on Stratigraphy

For details, please visit CGMW website: http://Www.ccgm.org

Commission for the Geological Map of the World Commission de la Carte Geologique du Monde 77 , rue Claude-Bernard 75005 Paris, France ccgm@club-internet.fr 